\title{
Discurso de Agradecimento do Professor Dr. J. J. Cardoso de Melo Neto, à homenagem que lhe prestou a Congregação da Faculdade conferindo-lhe o Título de Professor Emérito.
}

Realizou-se na manhã de 14 de novembro de 1953 na Faculdade de Direito, a sessão solene de encerramento do curso Juridico do ano letivo. Durante a cerimônia, a Congregação da Faculdade de Direito prestou significativa homenagem ao prof. José Joaquim Cardoso de Melo Neto, que acabava de ser aposentado, conferindo-lhe o título de Professor Emérito. À cerimônia compareceram além do corpo docente e alunos da Faculdade, numerosos amigos e admiradores do homenageado. Em nome da Congregação falou o prof. Teotônio Monteiro de Barros, que relembrou os serviços prestados pelo prof. Cardoso de Melo Neto à Faculdade de Direito, na cadeira de Economia Política, e ao país, nos altos cargos que ocupou, entre os quais o de governador de São Paulo e deputado federal.

Agradecendo a homenagem que recebia, o prof. Cardoso de Melo Neto pronunciou o seguinte discurso:

Esta manhã, de um São Paulo trepidante de progresso, transporta-me para a inesquecível manhã de um São Paulo, provinciano, em que, pela primeira vez, penetrei as arcadas do velho Convento de São Francisco.

Senti desde logo ser aqui o lugar em que seria traçado o meu destino, como aqui traçado fôra o destino dos meus: 
de meu avô, bacharel de 1858 . de meu pai, bacharel de 1880 e de todos os meus quatro tios.

Éramos menos de setenta estudantes, desde logo ligados por uma amizade que a luta acadêmica só conseguiu tornar indestrutívei, pelo tempo, porque alicerçada nas "tradições de aplicação ao estudo, de respeito aos mestres, de interêsse pelos problemas pátrios, dentro da ordem Constituída, que foram sempre a norma de proceder dos estudantes de direito de São Paulo" (discurso de posse na Faculdade de Direito - 1917).

Neste momento, em que a honra a mim conferida tem o dom de mais me comover que de orgulhar-me, quero sintetizar na saudade daquele que, no julgamento da Congregação e no nosso, foi o primus-inter-pares da turma de 1905 - José de Paula Rodrigues Alves — a gratidão filial à Faculdade de Direito, dos moços do principio do seculo, cuja vida se iniciou dentro duma revisão geral de todos os valores, de tôdas as ideologias, de todos os regimes, mas geração que não se perdeu, porque ficou fiel a esta Casa, isto é, ao Direito que ensina, à Moral Cristã, que pratica, à Patria que ama e serve.

Um dia, volto à Faculdade como professor substituto.

"Herculano de Freitas, diretor e meu antigo mestre, uma das mais formosas inteligências e um dos mais áticos espíritos, que iluminaram a Academia, envolveu-me numa atmosfera de carinho paternal, que, mantida, deu-me alento para vencer os primeiros e decisivos passos.

O que então disse devo recordá-lo para, num exame de consciência, pôr, ao lado do que prometi, o que realmente consegui fazer. Isto é, se à enfatica declaração, só compreensível num moço que acabava de "ver realizada a sua mais alta aspiração na vida pública", de que "os doutores da Faculdade estivessem certos de que não cairam em terreno sáfaro os seus votos, nem dêles, em dia algum, teriam 
ocasião de se arrepender". correspondeu um estilo de vida à altura do compromísso.

Imediatamente, após a posse, entreì no exercicio de ambas as cadeiras que formavam a antiga $5 .^{a}$ seçâo: Direito administrativo e Ciência da Administração, Economia Política e Ciência das Finanças.

"O retraimento da esperança que foi Dário Ribeiro e o mandato federal do insigne Manoel Vilaboim os afastava dos trabalhos escolares.

"Se os alunos do $2 .^{\circ}$ ano receberam o novo professor. apenas com a curiosidade da estréia, a atmosfera no 5. ano não era positivamente simpática. Mas, os moços são sempre os mesmos, ativos mas generosos, assomados, mas compreensivos, capazes, por isso, de transformar, num iñstante, um pré-julgamento apressado numa simpatia envolvente. $E$ foi o que se deu.

"Dez alunos de 1918 e 1919, ora com assento na Congregação, poderão dar testemunho do esfôrço que precisei despender para estar ao nível da substituição de Vilaboim. Tudo isso acrescido com a responsabilidade singular de manter o ensino de Economia e Finanças, na altitude a que a tinha levado o emérito Almeida Nogueira.

"E foi assim que comecei, dando tudo pela Academia e foi assim que continuei.

"Nunca dei uma aula, sem haver na vespera estudado o ponto. Tomei como norma de ação jamais esquecer de que a única distinção entre o professor e o aluno está no fato deste não precisar saber a lição, porque confia no colega mais antigo, que é o professor.

"Tive a preocupação constante de ser claro, ainda que aos doutos pudesse parecer superficial. Porque entendia e entendo que o professor não dá aula para seu prazer 
intelectual mas para o aluno, jejuno no assunto. Porque vi sempre, em cada estudante, uma matéria prima a ser moldada na forma da profissão e não um assistente de conferências, indiferente, ou um concorrente diante do qual a vaidade levasse a exibir ciência, tanto mais falsa, quanto mais apresentada em têrmos arrevesados.

“Tive sempre presente a orientação que, um dia, ainda estudante, recebi do grande Almeida Nogueira, tão severo nos concursos, quanto humano nos exames. A diferença entre a posição do professor, em um e outro cású, está em que, no exame, o professor procura, numa ginástica intelectual, às vêzes cansativa, indagar do minimo do conhecimento do aluno, ao passo que, no concurso, o examinador precisa ir ao fundo para verificar o que o candidato não sabe. Num, o mínimo, no outro, o máximo do conhecimento de cada um.

"Fui sempre amigo de meus alunos. Tratei-oś como filhos. Servi-os no quê pude. Mas, nunca cortejei a popularidade, nem me afastei, uma linha, da disciplina. Disciplina, que não se confunde com rispidez, nem mesmo com severidade. Disciplina, base da ordem, sem a qual a sociedade humana se deteriora e perece, porque não organizada à semelhança da ordem instituída pelo Criador.

"Diretor, numa época anormal, mantive a disciplina da Casa, mas deixei o cargo, diante de um ataque estúpido ao Centro "11 de Agosto", por não ter obtido reparaçâo incontinenti do atentado.

"Procurei resguardar as lídimas tradições da Academia do Largo São Francisco, às vêzes vivamente, segundo meu temperamento.

"Defendi a autonomia da Mocidade, isto é, a direção própria na consecução de seus ideais, porque filho desta Casa, aprendi a amá-la, mesmo antes de conhecê-la.

"Ainda que, fora da Academia, tive para ela sempre os olhos e o espírito voltados. São minhas estas palavras de janeiro de 1938: "Não vos arreceeis de que o destino, 
que me fêz mudar ainda que transitòriamente, a rota de minha existência, me faça esquecer-vos. É, ali, naquele templo, ao vosso lado, que eu quero passar a minha vida (Discurso de paraninfo, na Escola “Alvares Penteado).

Meus colegas,

"Acabais de conferir-me o mais alto prêmio que um professor pode almejar. Rejubílo-me, não porque entenda que intrinsecamente o mereça. Sem falsa modéstia vos digo, que não merece recompensa quem apenas procurou cumprir o seu dever.

"Agradeço, desvanecido, a excepcional investidura, porque estou convicto de que quisestes dar uma ilusão de mocidade, conservando-o na Consagração, a um colega que convosco vive há 36 anos, dentro duma amizade jamais esmorecida.

"Aceito-a porque entendestes e bem que homens unidos, como um feixe, pela vocação, sòmente a morte terá fôrça para separar."

Folha da Manhã-18-11-53. 